medRxiv preprint doi: https://doi.org/10.1101/2021.07.07.21260121; this version posted July 7,2021 . The copyright holder for this preprint (which was not certified by peer review) is the author/funder, who has granted medRxiv a license to display the preprint in perpetuity.

All rights reserved. No reuse allowed without permission.

\title{
SARS-COV-2 IGG DETECTION IN HUMAN ORAL FLUIDS.
}

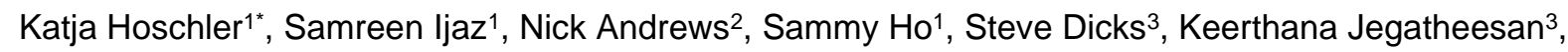
John Poh¹, Lenesha Warrener', Thivya Kankeyan¹, Frances Baawuah², Joanne Beckmann ${ }^{4}$, Ifeanichukwu O Okike ${ }^{5}$, Shazaad Ahmad ${ }^{6}$, Joanna Garstang7, Andrew J Brent ${ }^{8}$, Bernadette Brent ${ }^{8}$, Felicity Aiano², Kevin E Brown², Mary E Ramsay², David Brown ${ }^{9}$, John V Parry ${ }^{1}$, Shamez N Ladhani $^{10}$, Maria Zambon ${ }^{1}$.

*Correspondence: Dr Katja Hoschler, Virus Reference Department, Public Health England, 61 Colindale Avenue, London NW9 5EQ, UK. Email: Katja.Hoschler@phe.gov.uk

Word Count: Abstract 250 words, Main Text (excluding references, legends, tables and figures) 3,017 words

Key words: Oral fluid, antibody, COVID-19, schools, surveys, children

\section{AFFILIATIONS:}

1) Virus Reference Department, Public Health England, 61 Colindale Avenue, London NW9 $5 E Q, U K$,

2) Immunisation and Countermeasures Division, Public Health England, 61 Colindale Avenue, London NW9 5EQ, UK.

3) Virus Reference Department, Public Health England, 61 Colindale Avenue, London NW9 5EQ, UK; Microbiology Services Laboratory, NHS Blood and Transplant

4) East London NHS Foundation Trust, 9 Alie Street, London E1 8DE, UK

5) Derbyshire Healthcare NHS Foundation Trust, 201 London Road, Derby DE1 2TZ, UK

6) Manchester University NHS Foundation Trust, Oxford Road, Manchester M13 9WL, UK

7) Birmingham Community Healthcare NHS Trust, Holt Street, Aston B7 4BN, UK

8) Oxford University Hospitals NHS Foundation Trust, Old Road, Oxford OX3 7HE; University of Oxford, Wellington Square, Oxford OX1 2JD, UK

9) Virus Reference Department, Public Health England, 61 Colindale Avenue, London NW9 5EQ, UK; Fundação Oswaldo Cruz-Fiocruz, Instituto Oswaldo Cruz, Laboratório de Vírus Respiratórios e do Sarampo, Rio de Janeiro, RJ, Brasil.

10) Immunisation and Countermeasures Division, Public Health England, 61 Colindale Avenue, London NW9 5EQ, UK; Paediatric Infectious Diseases Research Group, St. George's University of London, London SW17 ORE, UK. 
medRxiv preprint doi: https://doi.org/10.1101/2021.07.07.21260121; this version posted July 7,2021 . The copyright holder for this preprint (which was not certified by peer review) is the author/funder, who has granted medRxiv a license to display the preprint in perpetuity.

All rights reserved. No reuse allowed without permission.

$\mathrm{KH}, \mathrm{SI}, \mathrm{SH}, \mathrm{TK}, \mathrm{KJ}$ and JP developed the assays and performed the laboratory analyses. NA and JVP performed the data analysis. SNL, FB, JB, IOO, SA, JG, AJB, BB, KEB, and MER devised, set up and recruited the sKIDs cohort and initiated and completed all the clinical sampling associated with sample acquisition. SL, JP, DB, SI, MZ and $\mathrm{KH}$ led on data interpretation and writing of the manuscript. All authors reviewed the data, discussed the results and commented on the manuscript.

ACKNOWLEDGEMENTS

The authors would like to thank the schools, headteachers, staff, families and their children who took part in the sKIDs surveillance. The authors would also like to thank the staff in the Virus Reference

42 Division at PHE Colindale, who supported antibody assay development, sample testing and, staff at the Immunisation and Countermeasures Division for creation and maintenance of the study database. Furthermore, we thank members of the Department of Education, Department of Health and Social Care, London School of Hygiene and Tropical medicine (LSHTM), Office for National Statistics (ONS) and Scientific Advisory Group for Emergencies (SAGE) for their input and support for the sKIDs surveillance.

\section{FUNDING}


medRxiv preprint doi: https://doi.org/10.1101/2021.07.07.21260121; this version posted July 7,2021 . The copyright holder for this preprint (which was not certified by peer review) is the author/funder, who has granted medRxiv a license to display the preprint in perpetuity.

All rights reserved. No reuse allowed without permission.

Katja Hoschler ${ }^{1 *}$, Samreen ljaz ${ }^{1}$, Nick Andrews², Sammy Ho ${ }^{1}$, Steve Dicks ${ }^{3}$, Keerthana Jegatheesan ${ }^{3}$, John Poh', Lenesha Warrener ${ }^{1}$, Thivya Kankeyan', Frances Baawuah², Joanne Beckmann ${ }^{4}$, Ifeanichukwu O Okike ${ }^{5}$, Shazaad Ahmad ${ }^{6}$, Joanna Garstang ${ }^{7}$, Andrew J Brent ${ }^{8}$, Bernadette Brent ${ }^{8}$, Felicity Aiano², Kevin E Brown², Mary E Ramsay², David Brown ${ }^{9}$, John V Parry ${ }^{1}$, Shamez N Ladhani ${ }^{10}$, Maria Zambon ${ }^{1}$.

\section{ABSTRACT}

Seroepidemiological studies to monitor antibody kinetics are important for assessing the extent and spread of SARS-CoV-2 in a population. Non-invasive sampling methods are advantageous to reduce the need for venepuncture, which may be a barrier to investigations particularly in paediatric populations. Oral Fluids are obtained by gingiva-crevicular sampling from children and adults and are very well accepted. ELISA based on these samples have acceptable sensitivity and specificity compared to conventional serum-based antibody ELISAs and are suitable for population-based surveillance.

We describe the development and evaluation of SARS-COV-2 IgG ELISAs using SARS-CoV-2 viral nucleoprotein (NP) and spike (S) proteins in IgG isotype capture format and an indirect receptorbinding-domain (RBD) IgG ELISA, intended for use in children. All three assays were assessed using a panel of 1999 paired serum and oral fluids from children and adults participating in national primary school SARS-CoV-2 surveillance studies during and after the first and second pandemic wave in the UK. The anti NP IgG capture assay was the best candidate, with an overall sensitivity of $75 \%$ (95\% Cl: $71-79 \%)$ specificity of $99 \%$ (95\% Cl: 78-99\%) when compared with paired serum antibodies measured using a commercial assay SARS-CoV-2 nucleoprotein IgG assay (Abbott, Chicago, IL, USA). Higher sensitivity was observed in children (80\%, $95 \% \mathrm{Cl}: 71-88 \%)$ compared to adults $(67 \%$, Cl: 60\%-74\%). Oral fluid assays using spike protein and RBD antigens were also 99\% specific and achieved reasonable but lower sensitivity in the target population (78\%, 95\% $\mathrm{Cl}(68 \%-86 \%)$ and $53 \%$, $95 \% \mathrm{Cl}(43 \%-64 \%)$, respectively).

\section{Conclusion statement:}

Oral Fluid assays based on the detection of SARS-CoV-2 antibodies are a suitable tool for population based seroepidemiology studies in children. 
medRxiv preprint doi: https://doi.org/10.1101/2021.07.07.21260121; this version posted July 7,2021 . The copyright holder for this preprint (which was not certified by peer review) is the author/funder, who has granted medRxiv a license to display the preprint in perpetuity.

All rights reserved. No reuse allowed without permission.

\section{INTRODUCTION}

SARS-CoV-2 virus causes coronavirus disease 2019 (COVID-19), primarily a self-limiting upper respiratory illness, but can be severe and fatal, especially in older adults $(1,2)$. Severe COVID-19 is associated with pneumonia and multi system damage (3) whereas asymptomatic, mild and subclinical infection is common, particularly in children and adolescents (4). Testing only symptomatic individuals for acute SARS-CoV-2 infection misses a significant proportion of cases and, therefore, underestimates the scale and spread of infection, which is critical for understanding transmission. The presence of SARS-CoV-2 antibodies provides a more robust measure of prior infection, irrespective of symptom status. Large-scale seroepidemiological programs provide crucial evidence in the monitoring of the progress of the pandemic and the impact of control measures allowing modelling of the patterns and trends in antibody responses in the population.

The scale of SARS-CoV-2 infection in children and young people is uncertain, and their role in infection and transmission remains unclear $(5,6)$. Seroepidemiological programmes based on testing of residual blood donations and clinical microbiology samples have yielded insights into progress of the pandemic in England in adults $(7,8)$, but an important barrier for such programmes, particularly in younger adults and children, is the availability of large numbers of representative blood samples.

The use of oral fluid (OF) for infection surveillance was pioneered in the UK, where it has been successfully used across a range of pathogens for several decades and to support the evaluation of the childhood vaccine programme(9-13). Collection is suited to sampling populations such as children and underserved groups because it does not require the use of venepuncture. The specimen can be self-collected, guided by videos and pictorial instructions (9).

PHE initiated SARS-CoV-2 surveillance in primary schools across England (6). In total, 131 schools across England were recruited; 86 schools provided weekly nasal swabs for SARS-CoV-2 RT-PCR and 45 schools provided a blood sample, nasal swab and an oral fluid sample at the beginning and end of the autumn term in 2020 (6), providing population based materials to assess the feasibility and performance of oral fluid tests. In this study, we evaluated three different in-house enzyme immunoassays (EIA) for SARS-CoV-2 antibodies in OF against paired blood samples taken from children participating in a national surveillance programme.

\section{MATERIALS AND METHODS}

\section{Ethics Statement}

The work described here falls outside of the Health Research Authority remit for ethical review. This is in accordance with the revised guidance in the Governance Arrangements for Research Ethics Committees (GAfREC) that was released in September 2011. The surveillance protocol has been subject to an internal ethical review by the PHE Research Ethics and Governance Group, to ensure that it is fully compliant with all regulatory requirements and was approved by the Public Health England Research Ethics Governance Group (R\&D REGG Ref: NR0209, 16 May 2020). 
medRxiv preprint doi: https://doi.org/10.1101/2021.07.07.21260121; this version posted July 7,2021 . The copyright holder for this preprint (which was not certified by peer review) is the author/funder, who has granted medRxiv a license to display the preprint in perpetuity.

All rights reserved. No reuse allowed without permission.

\section{Recruitment and Sample collection}

Headteachers in participating primary schools sent the study information pack to parents and staff at the start of the study and those interested in taking part were asked to sign a consent form and complete a short questionnaire. PHE investigators attended the school premises in the period from 28th May - 10th July 2020 and took nasal swabs and blood samples from participating children and provided guidance and supervision of the oral fluid self-sampling (Table S1, Supplementary information).

The oral fluids were collected on the same day as the paired venous blood, using the Oracol ${ }^{\mathrm{TM}}$ foam swab. This collects gingiva-crevicular fluid when brushing the gum line for 2 minutes, after which the swab is re-inserted into a plastic container for transportation. Samples are stable for transport at ambient temperature $(14,15)$. All samples were couriered to PHE Colindale for same-day processing and storage.

\section{Oral fluid extraction from Oraco/ ${ }^{\mathrm{TM}}$ swab}

On receipt in the laboratory, OF was extracted from the foam swab using $1 \mathrm{ml}$ of an elution buffer (Phosphate buffered saline containing 10\% Foetal Calf serum and 250ug/ml Gentamicin and 0.5ug/ml Fungizone), The swab tube was centrifuged at $3000 \mathrm{~g}$ for 5 minutes in bench top centrifuge to remove cellular debris and, the swab removed and discarded. Samples were stored at $-20 \mathrm{C}$ prior to testing.

\section{Oral Fluid Assays}

Three EIAs were each based on the use of 96-well microplates, and comprised:

(i) an indirect EIA based on a solid-phase Receptor Binding Domain (RBD) antigen of S protein and HRP-conjugated anti-human IgG probe (RBD25);

(ii) $\lg$ isotype antibody capture (GICAP) EIAs based on a solid-phase anti-human IgG with an HRP-conjugated viral NP probe; or.

(iii) GICAP EIAs based on a solid-phase anti-human IgG with an HRP-conjugated full-length viral Spike protein probe 
medRxiv preprint doi: https://doi.org/10.1101/2021.07.07.21260121; this version posted July 7,2021 . The copyright holder for this preprint (which was not certified by peer review) is the author/funder, who has granted medRxiv a license to display the preprint in perpetuity.

All rights reserved. No reuse allowed without permission.

\section{Laboratory Analysis of oral fluids and sera}

\section{IgG Capture ELISA NP and S}

Solid-phase wells (NUNC Immunomodule, U8 Maxisorp wells) were coated with $100 \mu$ l volumes of Affinipure rabbit anti-human $\gamma$ (Jackson ImmunoResearch, Ely, Cambridgeshire UK) at $5 \mu \mathrm{g} / \mathrm{ml}$ in Microlmmune Coating Buffer for ELISA with preservative; (ClinTech, Guildford, UK). Coating was overnight at $2-8^{\circ} \mathrm{C}$, followed by 3 hours at $35-37^{\circ} \mathrm{C}$. Wells were then washed with PBS Tween 20 and quenched with Microlmmune Blocking Solution (ClinTech, Guildford, UK) for $3-4$ hours at $37^{\circ} \mathrm{C}$. Wells were aspirated and stored dry at $4^{\circ} \mathrm{C}$ in sealed pouches with desiccant until use. For both the NP and $S$ Capture ELISAs, $100 \mu \mathrm{l}$ of oral fluid were added to the wells, incubated for $60 \pm 2$ minutes at $37^{\circ} \mathrm{C}$ prior to washing and the addition of the conjugate. One hundred microlitres of HRP conjugated SARSCoV-2 full length Spike Glycoprotein (Native Antigen, Oxford, UK) or HRP conjugated SARS-CoV-2 Nucleoprotein (Native Antigen, Oxford, UK) were added to the microwells for the S and NP assays respectively. After a further incubation for $60 \pm 2$ minutes at $37^{\circ} \mathrm{C}$ the solid-phase was again washed and $100 \mu \mathrm{l}$ of substrate added, incubated for $30 \pm 2$ minutes at $37^{\circ} \mathrm{C}$, the reaction then stopped and measured at $450 / 630 \mathrm{~nm}$.

\section{Indirect anti-RBD IgG ELISA}

Oral fluids were analysed with an ELISA established for analysis of sera (16). This indirect ELISA was modified to allow analysis of oral fluids as follows: 96-well microtiter plates (Nunc, Cat-439454) were coated with recombinant SARS-CoV-2 RBD (Sino Biological Inc, 25ng/well) incubated with sample at 1:50, and $\lg G$ in $O F$ was detected using Biotin conjugated anti-human $\lg G(F c)$ (eBiosciences, Cat: 13-4998-83) followed by detection of the human $\lg G$ - anti-human $\lg G(\mathrm{Fc})$ complexes using Streptavidin poly HRP (Thermoscientific, Cat- N200). For analysis, mean optical density (OD) values were calculated for each study sample, controls and negative OF. Oral fluid samples from SARSCoV-2 antibody seronegative individuals and taken prior to the COVID-19 pandemic were used as negative controls. Results are presented as ratios of the optical density (OD) of the sample to the OD of the true negative (TN), analysed on the same plate. OD/TN ratios of greater than or equal to 5.0 and 3.0 for serum and OF, respectively, were considered positive.

The cut-off value for OF samples for all assays was determined by age group (children and adults) from the serum-OF pairs, using exploratory sensitivity versus specificity analysis (see supplement Figure S1 and Table S2) with the result from the commercial serum test considered the true result. The final cut-off was the value with the highest possible sensitivity retaining the specificity minimum of $98 \%$ in both age groups. The final cut-offs where then evaluated by Area Under the Curve (AUC) Receiver Operating Characteristics (ROC) curve analysis.

\section{Analysis with commercial EIA}

Contemporaneously collected serum samples were tested for SARS-CoV-2 IgG Abbott Architect SARS-CoV-2 IgG kit; REF 6R86); following the manufacturer's instruction using a cut-off above 0.8 to determine positivity. SARS-CoV-2 IgG antibody concentrations in oral fluid were measured using the IgG Human SimpleStep ELISA Kit (Abcam ab195215) according to the manufacturer's instruction. 
medRxiv preprint doi: https://doi.org/10.1101/2021.07.07.21260121; this version posted July 7,2021 . The copyright holder for this preprint (which was not certified by peer review) is the author/funder, who has granted medRxiv a license to display the preprint in perpetuity.

All rights reserved. No reuse allowed without permission.

\section{Statistical analysis}

Sensitivity and Specificity relative to the Abbott testing on serum was calculated with $95 \%$ exact confidence intervals. This was done at a range of cut-offs by ROC-curve analysis which informed on the optimal cut-offs. The area under the ROC curve was also calculated with $95 \%$ confidence intervals as an overall measure of assay performance. Assays were compared visually using scatter plots with logged scaled axes and lines of best fit added and the index of multiple correlation calculated (R2). This was also done to compare results to total lgG. Total lgG was compared between those positive and negative by Abbott on serum using Tobit regression.

\section{RESULTS}

Paired serum and OF samples from 1,999 subjects were tested (Table S1). SARS-CoV-2 antibody seropositivity was confirmed in $12 \%(92 / 746)$ of children and $16 \%(196 / 1,253)$ of staff from blood samples taken during the period of May - July 2020, which is comparable to age-matched antibody seroprevalence in the local community at the time(6). All OF specimens were assayed for total lgG concentration. The overall distribution of total IgG in OF collected from students and staff indicated that 20/1,999 (1.0\%) OF specimens had undetectable IgG titres and a further $67 / 1,999$ (3.3\%) had an IgG concentration $>0.1 \mathrm{mg} / \mathrm{L}$ and $<1.0 \mathrm{mg} / \mathrm{L}$. Thus, $95.7 \%(1913 / 1,999)$ had an $\operatorname{lgG}$ concentration $\geq 1 \mathrm{mg} / \mathrm{L}$, with the vast majority $(86.8 \%(1736 / 1,999)) \geq 2.0 \mathrm{mg} / \mathrm{L}$. Total $\mathrm{IgG}$ concentrations were not strongly associated with SARS-CoV-2 antibody positivity (Figure 2). Tobit analysis of logged total IgG with censoring of $\lg G$ concentrations at 1 and 15 and with adjustment for adult/children showed that the concentration was slightly higher (1.32-fold, $95 \% \mathrm{Cl}(1.13-1.55)$ in those positive compared to those negative. Children were more likely than adults to provide an OF with no detectable (14/746 [1.9\%] versus $6 / 1,253$ [0.5\%]) or low (0.2-1 $\mathrm{mg} / \mathrm{L}) \mathrm{lgG}$ antibody titres $(57 / 746$ [7.6\%] versus 10/1253 $[0.8 \%])$.

\section{Performance of three OF EIA's}

Comparison of serum with oral fluid IgG antibody titres using each of the three OF assays showed a strong and statistically significant quantitative correlation between the serum IgG signal/cut-off (S/CO) ratio and each of the oral fluid ELISA antibody titres (Figure 1). The number of discordant results, with antibody detectable in blood, but not in OF, was most evident with the RBD ELISA, and least evident with the anti-NP IgG capture ELISA (GICAP). The sensitivities of the GICAP EIAs (NP: $80 \%$ \& Spike: 78\%) were significantly better than the indirect EIA (RBD: 53\%) when testing OFs from children, while specificities were similar, at 99\% (Table 1 and Figure S1). ROC curve analysis confirmed the superiority of the NP and S GICAP EIAs over the indirect RBD ELISA in the correct classification of oral fluids from children, with the area under the curve (AUC) for both assays statistically larger than for the RBD ELISA. For OFs from adults (staff), sensitivities were overall lower than for children and the AUC were comparable, but the NP GICAP EIA was the most sensitive and offered marginally better specificity than the S GICAP and RBD EIA. 
medRxiv preprint doi: https://doi.org/10.1101/2021.07.07.21260121; this version posted July 7,2021 . The copyright holder for this preprint (which was not certified by peer review) is the author/funder, who has granted medRxiv a license to display the preprint in perpetuity.

All rights reserved. No reuse allowed without permission.

\section{Utility of Testing Each Oral Fluid Specimen for Total IgG Content}

222 Total IgG concentrations in OracolTM OF samples increased with age (Figure 3). Overall, there was poor correlation between total IgG concentrations and SARS-CoV-2 IgG antibody titres for each of the three OF ELISAs, although there was a declining trend in RBD ELISA IgG titres associated with declining total IgG concentration for both children and staff (Figure 4). For the GICAP ELISAs, such a trend was absent for OF samples from children, although there was a modest declining trend in SARS-CoV-2 lgG antibody titres as total lgG concentrations fell, but much less pronounced than observed with the RBD ELISA. When OF anti-NP ELISA sensitivity was stratified based on total lgG concentration, the overall sensitivity remained unchanged until total lgG concentration fell to $<1 \mathrm{mg} / \mathrm{L}$ (Figure 4). While OF results in children maintained high sensitivity at all lgG concentrations $>1 \mathrm{mg} / \mathrm{L}$, sensitivity in adults declined as total lgG fell.

It was not possible to identify a clear boundary at which total IgG was associated with loss of sensitivity for SARS-CoV-2 NP IgG detection. An arbitrary total lgG threshold of $0.2 \mathrm{mg} / \mathrm{L}$, or even $1 \mathrm{mg} / \mathrm{L}$, would exclude only $1 \%$ or $4.3 \%$ of negative specimens, respectively, from prevalence estimates. This would lead to very small changes in measured prevalence; for example, a seroprevalence of $20 \%$ would change to $20.2 \%$ or $20.7 \%$, respectively.

\section{DISCUSSION}

This study forms part of a national programme of SARS-CoV-2 infection and transmission studies in primary schools whereby paired samples were taken from students and staff to estimate acute infection and seroprevalence over a six-month period. As part of the study, contemporaneous OF samples were taken to develop and validate a non-invasive alternative to blood sampling for seroepidemiological surveillance applications and for use in outbreak investigations.

Several viral antigens were evaluated. Viral NP and S proteins are most frequently used in commercial immunoassays (17). Each virion carries on average more than 2000 copies of the nonglycosylated NP protein and some data suggests that SARS-CoV-2 NP antibody detection may be more sensitive than S protein antibody for detecting early infection (18). The NP of SARS-CoV-2 shows between $58 \%$ and $65 \%$ similarity to NP of seasonal coronaviruses, and cross-reactivity has been observed in multiple studies $(19,20)$. The S protein, specifically the RBD region of this protein, is the target for neutralising antibodies and, antibodies against the $S 1$ subunit of the spike protein or against RBD have been observed to correlate with neutralising antibody, although not all spike/RBD antibodies detected in binding assays confer neutralisation (21). approximately $1 / 1,000$ of that in blood plasma. As a result, antibody tests using OFs tend to have lower sensitivity than those designed for serum, but this analyte is successfully used in seroepidemiology studies for other viruses e.g. measles and HIV (22-24). The concentration of OFs 
medRxiv preprint doi: https://doi.org/10.1101/2021.07.07.21260121; this version posted July 7,2021 . The copyright holder for this preprint (which was not certified by peer review) is the author/funder, who has granted medRxiv a license to display the preprint in perpetuity.

All rights reserved. No reuse allowed without permission.

varies between individual specimens, ranging from $<0.5 \mathrm{mg} / \mathrm{L}$ to $>30 \mathrm{mg} / \mathrm{L}$ (14). This variability in $\mathrm{IgG}$ concentrations makes the choice of assay format more critical. Generally, GICAP antibody tests have proved to be most robust when detecting viral antibodies in OFs as they are tolerant to the very wide range of IgG concentration. The strength of any reactivity in a capture assay is dependent on the proportion of total IgG that is specific for the target antigen, in this case, the SARS-CoV-2 viral proteins. Consequently, as long as there is sufficient total $\lg G$ to saturate the anti-lgG binding sites on the solid phase, the quantity of captured antibodies, while only a part of the total IgG captured, will be constant. In our study, measurement of total IgG content to assess OF sample quality revealed a strong correlation with RBD ELISA reactivity, but not with NP or S protein ELISAs. This reflects the greater robustness of the IgG isotype capture ELISAs when testing clinical samples, including OFs, that have highly variable total IgG content. This observation provides some insight into the differences in anti-SARS-CoV-2 antibody sensitivity between the different OF assays assessed. We also confirmed lower OF IgG concentrations in young children, which increases with age, reflecting plasma IgG levels which also increase with age, and this probably explains why the RBD EIA sensitivity was lower in children than in staff. Other reasons for lower IgG content in children's oral fluids may be physiological or, in some cases, failure to follow instructions, such as not collecting an OF sample for the recommended 2 minutes. Overall however the low number of inadequate samples $(<2 \%)$ and the additional costs and demands on laboratory time and facilities associated with measuring total IgG for every OF sample far outweigh the marginal gain of confirming the quality of the sample for measuring SARS-CoV-2 antibodies when there is very little impact on assay performance.

By comparing three different OF SARS-CoV-2 antibody assays, we found that the sensitivities of the IgG isotype capture ELISAs ( $80 \%$ for NP, $78 \%$ for $S$ ) were significantly higher than the indirect ELISA (RBD, 53\%) when testing OFs from children, while specificities were similar at 99\% for all three assays. These results are in keeping with other studies (25-28). Comparison between the two capture assays is consistent with previous findings that assays based on NP antibodies were more sensitive than $\mathrm{S}$ antibody assays, with the added advantage that anti-NP assays provide earlier detection after infection compared to $S$ protein antibodies $(18,29)$. Using multiple antigen formulations in a multiplex magnetic microparticle assay, the performance with NP based antigens for OFs from adults was consistently more sensitive than Spike based assays (27). The choice of PCR detection as a reference comparator to assign infection status, rather than serum measurements of the same antibody as recently described by Pisanic et al.(27) will underestimate the number of infections, thereby providing an underestimate of serological prevalence and inflating the assumed sensitivity of the OF assay. A reference classification using a molecular detection assay and a serum antibody assay in combination and excluding samples from antibody negative, PCR positive individuals, is expected to improve sensitivity and specificity of an assessed OF assay, as demonstrated in (31).

As anticipated, overall sensitivity of detection of SARS CoV-2 IgG OF antibodies was lower than serum. However, we judge that all three in-house assays were sufficiently accurate for large-scale use in population-based studies, with statistical adjustment. Taking into consideration the three OF assays and, the reproducibility, robustness, reagent supply chain and sustainability of service 
medRxiv preprint doi: https://doi.org/10.1101/2021.07.07.21260121; this version posted July 7,2021 . The copyright holder for this preprint (which was not certified by peer review) is the author/funder, who has granted medRxiv a license to display the preprint in perpetuity.

All rights reserved. No reuse allowed without permission.

delivery, the IgG isotype specific SARS-CoV-2 NP capture EIA has been adopted as the principal test for the OF-based SARS-CoV-2 antibody surveillance studies in children. A limitation of using a single antigen assay, however, is that antibody kinetics may vary over time. Following mild SARS-CoV-2 infection, for example, serum nucleoprotein antibodies decline more rapidly than spike protein antibodies (19), but this may differ for severe illness and may be also dependent on the assays used (30). Additionally, little is known about antibody kinetics in children, which may differ over time since infection. It is, therefore, possible that exclusive use of the NP capture assay may need to be reevaluated in future, when antibody from naturally acquired infection starts to wane. Since current vaccines induce spike protein antibodies, inclusion of a spike protein antibody assay would allow distinction between antibodies induced following natural infection and/or vaccination, especially in the context of discussions around vaccination of children. We will continue to evaluate and re-assess the selected assay with longitudinal oral fluids and serum samples collected from in children and adult individuals with confirmed SARS-CoV-2 infection.

\section{REFERENCES}

1. Borczuk AC, Salvatore SP, Seshan SV, Patel SS, Bussel JB, Mostyka M, et al. COVID-19 pulmonary pathology: a multi-institutional autopsy cohort from Italy and New York City. Mod Pathol. $2020 \mathrm{Nov} ; 33(11): 2156-68$.

2. Dennis A, Wamil M, Alberts J, Oben J, Cuthbertson DJ, Wootton D, et al. Multiorgan impairment in low-risk individuals with post-COVID-19 syndrome: a prospective, community-based study. BMJ Open. 2021 Mar 30;11(3):e048391.

3. Bryce C, Grimes Z, Pujadas E, Ahuja S, Beasley MB, Albrecht R, et al. Pathophysiology of SARS-CoV-2: the Mount Sinai COVID-19 autopsy experience. Mod Pathol. 2021 Apr 1.

4. De Luca CD, Esposito E, Cristiani L, Mancino E, Nenna R, Cortis E, et al. Covid-19 in children: A brief overview after three months experience. Paediatr Respir Rev. 2020 Sep;35:9-14. 5. Ismail SA, Saliba V, Lopez Bernal J, Ramsay ME, Ladhani SN. SARS-CoV-2 infection and transmission in educational settings: a prospective, cross-sectional analysis of infection clusters and outbreaks in England. Lancet Infect Dis. 2021 Mar;21(3):344-53.

6. Ladhani SN, Baawuah F, Beckmann J, Okike IO, Ahmad S, Garstang J, et al. SARS-CoV-2 infection and transmission in primary schools in England in June-December, 2020 (sKIDs): an active, prospective surveillance study. Lancet Child Adolesc Health. 2021 Mar 16.

7. Public Health England. Serological Surveillance of COVID-19 in England: Sera collection protocol.

https://assets.publishing.service.gov.uk/government/uploads/system/uploads/attachment data/file/89 0007/s0036-serological-surveillance-of-covid-19-England-sera-collection-protocol-040320sage13.pdf; 2020.

8. Public Health England. National COVID-19 surveillance report: 2 October 2020 (week 40). https://www.gov.uk/government/publications/national-covid-19-surveillance-reports/sero-surveillanceof-covid-19; 2020.

9. $\quad$ Parry JV, Perry KR, Mortimer PP. Sensitive assays for viral antibodies in saliva: an alternative to tests on serum. Lancet. $1987 \mathrm{Jul} 11 ; 2(8550): 72-5$.

10. Perry KR, Brown DW, Parry JV, Panday S, Pipkin C, Richards A. Detection of measles, mumps, and rubella antibodies in saliva using antibody capture radioimmunoassay. J Med Virol. 1993 Jul;40(3):235-40.

11. Morris-Cunnington MC, Edmunds WJ, Miller E, Brown DW. A population-based seroprevalence study of hepatitis A virus using oral fluid in England and Wales. Am J Epidemiol. 2004 Apr 15;159(8):786-94. 
medRxiv preprint doi: https://doi.org/10.1101/2021.07.07.21260121; this version posted July 7,2021 . The copyright holder for this preprint (which was not certified by peer review) is the author/funder, who has granted medRxiv a license to display the preprint in perpetuity.

All rights reserved. No reuse allowed without permission.

12. Manikkavasagan G, Bukasa A, Brown KE, Cohen BJ, Ramsay ME. Oral fluid testing during 10 years of rubella elimination, England and Wales. Emerg Infect Dis. 2010 Oct;16(10):1532-8. 13. Maple PA. Application of Oral Fluid Assays in Support of Mumps, Rubella and Varicella Control Programs. Vaccines (Basel). 2015 Dec 9;3(4):988-1003.

14. Vyse AJ, Cohen BJ, Ramsay ME. A comparison of oral fluid collection devices for use in the surveillance of virus diseases in children. Public Health. 2001 May;115(3):201-7.

15. Public Health England. COVID-19 Surveillance in Children attending preschool, primary and secondary schools:. COVID-19 Surveillance in school KIDs (code: sKIDs).

https://www.gov.uk/government/publications/covid-19-surveillance-in-school-kids-skids-pre-andprimary-schools; 2020.

16. Harris RJ, Whitaker HJ, Andrews NJ, Aiano F, Amin-Chowdhury Z, Flood J, et al. Serological surveillance of SARS-CoV-2: Six-month trends and antibody response in a cohort of public health workers. J Infect. 2021 Mar 22.

17. Li D, Li J. Immunologic testing for SARS-CoV-2 infection from the antigen perspective. J Clin Microbiol. 2020 Dec 14.

18. Burbelo PD, Riedo FX, Morishima C, Rawlings S, Smith D, Das S, et al. Detection of Nucleocapsid Antibody to SARS-CoV-2 is More Sensitive than Antibody to Spike Protein in COVID-19 Patients. medRxiv. 2020 Apr 24.

19. McAndrews KM, Dowlatshahi DP, Dai J, Becker LM, Hensel J, Snowden LM, et al. Heterogeneous antibodies against SARS-CoV-2 spike receptor binding domain and nucleocapsid with implications for COVID-19 immunity. JCI Insight. 2020 Sep 17;5(18).

20. Anderson EM, Goodwin EC, Verma A, Arevalo CP, Bolton MJ, Weirick ME, et al. Seasonal human coronavirus antibodies are boosted upon SARS-CoV-2 infection but not associated with protection. Cell. 2021 Apr 1;184(7):1858-64 e10.

21. Amanat F, Thapa M, Lei T, Ahmed SMS, Adelsberg DC, Carreno JM, et al. The plasmablast response to SARS-CoV-2 mRNA vaccination is dominated by non-neutralizing antibodies that target both the NTD and the RBD. medRxiv. 2021 Mar 9.

22. Pascoe SJ, Langhaug LF, Mudzori J, Burke E, Hayes R, Cowan FM. Field evaluation of diagnostic accuracy of an oral fluid rapid test for HIV, tested at point-of-service sites in rural Zimbabwe. AIDS Patient Care STDS. 2009 Jul;23(7):571-6.

23. Roberts KJ, Grusky O, Swanson AN. Outcomes of blood and oral fluid rapid HIV testing: a literature review, 2000-2006. AIDS Patient Care STDS. 2007 Sep;21(9):621-37.

24. Vyse AJ, Gay NJ, White JM, Ramsay ME, Brown DW, Cohen BJ, et al. Evolution of surveillance of measles, mumps, and rubella in England and Wales: providing the platform for evidence-based vaccination policy. Epidemiol Rev. 2002;24(2):125-36.

25. Ben Salah A, Zaatour A, Pomery L, Cohen BJ, Brown DW, Andrews N. Validation of a modified commercial assay for the detection of rubella-specific IgG in oral fluid for use in population studies. J Virol Methods. 2003 Dec;114(2):151-8.

26. Saleh LH. The use of saliva for the detection of $\lg G$ and anti-bodies against rubella virus: comparison of indirect ELISA and antibody capture immunoassay. J Egypt Public Health Assoc. $1991 ; 66(1-2): 123-34$.

27. Pisanic N, Randad PR, Kruczynski K, Manabe YC, Thomas DL, Pekosz A, et al. COVID-19 Serology at Population Scale: SARS-CoV-2-Specific Antibody Responses in Saliva. J Clin Microbiol. 2020 Dec 17;59(1).

28. Isho B, Abe KT, Zuo M, Jamal AJ, Rathod B, Wang JH, et al. Persistence of serum and saliva antibody responses to SARS-CoV-2 spike antigens in COVID-19 patients. Sci Immunol. 2020 Oct 8;5(52).

29. Popovic M, Minceva M. Thermodynamic insight into viral infections 2: empirical formulas, molecular compositions and thermodynamic properties of SARS, MERS and SARS-CoV-2 (COVID19) viruses. Heliyon. 2020 Sep;6(9):e04943.

30. Huang C, Huang L, Wang Y, Li X, Ren L, Gu X, et al. 6-month consequences of COVID-19 in patients discharged from hospital: a cohort study. Lancet. 2021 Jan 16;397(10270):220-32. 
medRxiv preprint doi: https://doi.org/10.1101/2021.07.07.21260121; this version posted July 7,2021 . The copyright holder for this preprint (which was not certified by peer review) is the author/funder, who has granted medRxiv a license to display the preprint in perpetuity.

All rights reserved. No reuse allowed without permission.

400 FIGURE LEGENDS

401 Figure 1: Scattergrams of Abbot Architect IgG anti-SARS-CoV-2 S/CO determined in sera versus test

402 result determined from concomitantly collected and paired oral fluids analysed in: 1a) IgG Anti SARS-

403 CoV-2 (RBD, indirect format) 1b) IgG Anti SARS-CoV-2 (Spike, capture format) and 1c) IgG Anti

404 SARS-CoV-2 (NP, capture format). - All data log transformed. Data from children is shown in solid

405 black dots and samples from staff (adults) are shown in grey circles; numbers are shown in graph.

406 Dotted lines represent data trends in each assay.

407 Figure 2: Distribution of total IgG in OF by serum result (from Abbot Architect analyser)

408 Figure 3: Scattergram of Total IgG measured in Oral Fluid by age of subject (children only; 708

409 children with known age included. Dotted line indicates trend)

410 Figure 4: Scattergrams of total lgG concentration (in $\mathrm{mg} / \mathrm{L}$ ) determined in oral fluids versus test result

411 determined in: 1a) IgG Anti SARS-CoV-2 (RBD, indirect format) 1b) IgG Anti SARS-CoV-2 (Spike,

412 capture format) and 1c) IgG Anti SARS-CoV-2 (NP, capture format). Data from children is shown in

413 solid black dots and samples from staff (adults) are shown in grey circles. - All data log transformed.

414 The detection limit for the total $\mathrm{lgG}$ determination is $15 \mathrm{mg} / \mathrm{ml}$ - data points from samples with $\mathrm{lgG}$

$415>15 \mathrm{mg} / \mathrm{L}$ were excluded from graphs. Number of samples from children: $n=619$, number of samples

416 from adults/staff: $\mathrm{N}=695$. Dotted lines represent data trends in each assay, $\mathrm{R} 2$ values are given for

417 each trend. 
medRxiv preprint doi: https://doi.org/10.1101/2021.07.07.21260121; this version posted July $7,2021$. The copyright holder for this preprint (which was not certified by peer review) is the author/funder, who has granted medRxiv a license to display the preprint in perpetuity.

All rights reserved. No reuse allowed without permission.

Table 2: Sensitivity of GISAC EIA for detection of IgG anti-SARS-CoV-2 NP antibody in oral fluid specimens by total $\lg G$ concentration.

\begin{tabular}{|c|c|c|c|c|c|c|c|c|c|}
\hline IgG & \multicolumn{3}{|c|}{ Seropositive Children } & \multicolumn{3}{|c|}{ Seropositive Staff } & \multicolumn{3}{|c|}{ Seropositive Overall } \\
\hline Conc. & NP Positive & NP Negative & \% Positive & NP Positive & NP Negative & \% Positive & NP Positive & NP Negative & \% Positive \\
\hline$>10 \mathrm{mg} / \mathrm{L}$ & 22 & 7 & $75.9 \%$ & 94 & 39 & $70.7 \%$ & 116 & 46 & $71.6 \%$ \\
\hline $2-10 \mathrm{mg} / \mathrm{L}$ & 37 & 7 & $84.1 \%$ & 34 & 20 & $63.0 \%$ & 71 & 27 & $72.4 \%$ \\
\hline $1-2 \mathrm{mg} / \mathrm{L}$ & 12 & 2 & $85.7 \%$ & 3 & 3 & $50.0 \%$ & 15 & 5 & $75.0 \%$ \\
\hline$<1 \mathrm{mg} / \mathrm{L}$ & 2 & 2 & $50.0 \%$ & 0 & 2 & $0.0 \%$ & 2 & 4 & $33.3 \%$ \\
\hline Overall & 73 & 18 & $80.2 \%$ & 131 & 64 & $67.2 \%$ & 204 & 82 & $71.3 \%$ \\
\hline
\end{tabular}

Table 1: Sensitivity and specificity findings for the 3 Oral Fluid IgG anti-SARS-CoV-2 ELISAs at their optimal cut-off based on status based on a serum test in the Abbott Architect SARS-CoV-2 IgG Assay.

\begin{tabular}{|c|c|c|c|c|c|}
\hline & Cut-off & Sensitivity $(95 \% \mathrm{Cl})$ & $\mathrm{n} / \mathbf{N}$ & Specificity (95\% Cl) & $\mathrm{n} / \mathbf{N}$ \\
\hline \multicolumn{6}{|l|}{ Children $(\mathrm{n}=746)$} \\
\hline RBD indirect & 3.0 & $53 \%(43 \%-64 \%)$ & $49 / 92$ & $99 \%(98 \%-100 \%)$ & $649 / 654$ \\
\hline Spike capture & 1.0 & $78 \%(68 \%-86 \%)$ & $71 / 91^{a}$ & $99 \%(98 \%-100 \%)$ & $645 / 650^{\mathrm{b}}$ \\
\hline Nucleoprotein capture & 1.0 & $80 \%(71 \%-80 \%)$ & $73 / 91^{a}$ & $99 \%(98 \%-100 \%)$ & $644 / 650^{\mathrm{b}}$ \\
\hline \multicolumn{6}{|l|}{ Staff $(n=1,253)$} \\
\hline RBD indirect & 3.0 & $60 \%(53 \%-67 \%)$ & $117 / 196$ & $98 \%(97 \%-99 \%)$ & $1035 / 1057$ \\
\hline Spike capture & 1.0 & $58 \%(51 \%-65 \%)$ & $113 / 195^{c}$ & $99 \%(98 \%-99 \%)$ & $1044 / 1056^{d}$ \\
\hline Nucleoprotein capture & 1.0 & $67 \%(60 \%-74 \%)$ & $131 / 195^{c}$ & $99 \%(98 \%-99 \%)$ & $1041 / 1056^{\mathrm{d}}$ \\
\hline
\end{tabular}

a, b, d A single specimen from each of these categories was of insufficient volume to permit testing by the 2 lgG capture assays.

${ }^{c}$ Four specimens from this category were of insufficient volume to permit testing by the 2 lgG capture assays. 
medRxiv preprint doi: https://doi.org/10.1101/2021.07.07.21260121; this version posted July 7, 2021. The copyright holder for this preprint (which was not certified by peer review) is the author/funder, who has granted medRxiv a license to display the preprint in perpetuity.

All rights reserved. No reuse allowed without permission.

Figure 1: Scattergrams of Abbot Architect IgG anti-SARS-CoV-2 S/CO determined in sera versus test result determined from concomitantly collected and paired oral fluids

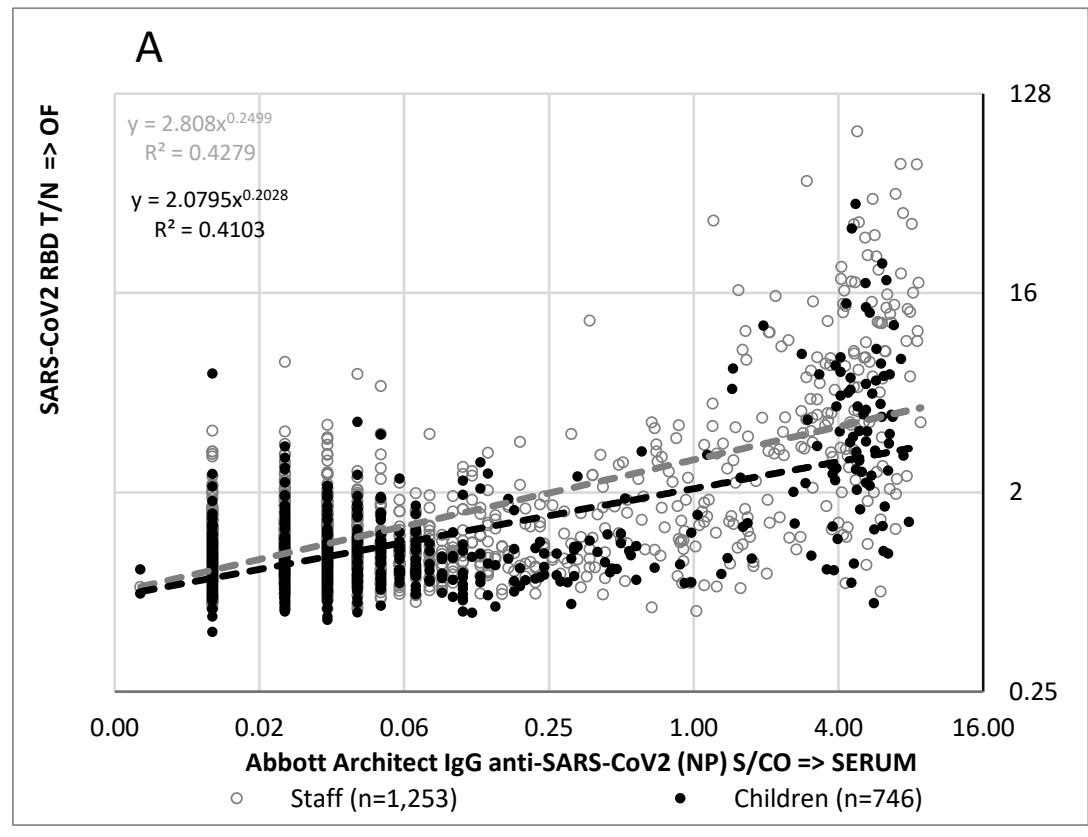

B

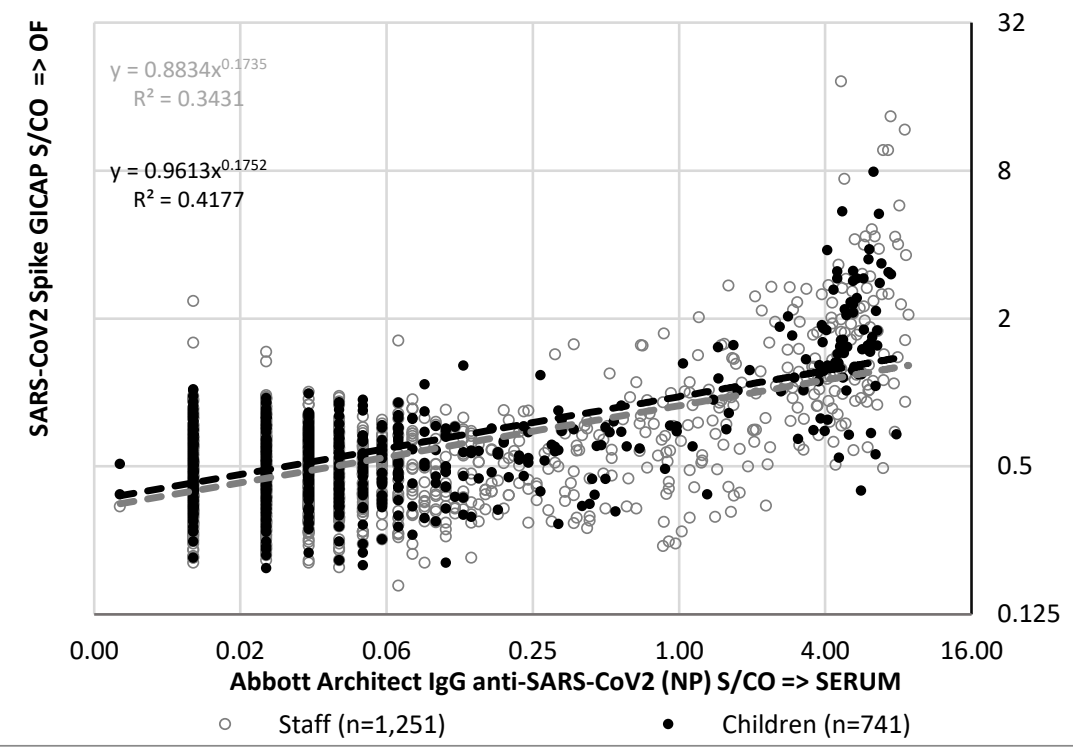

C

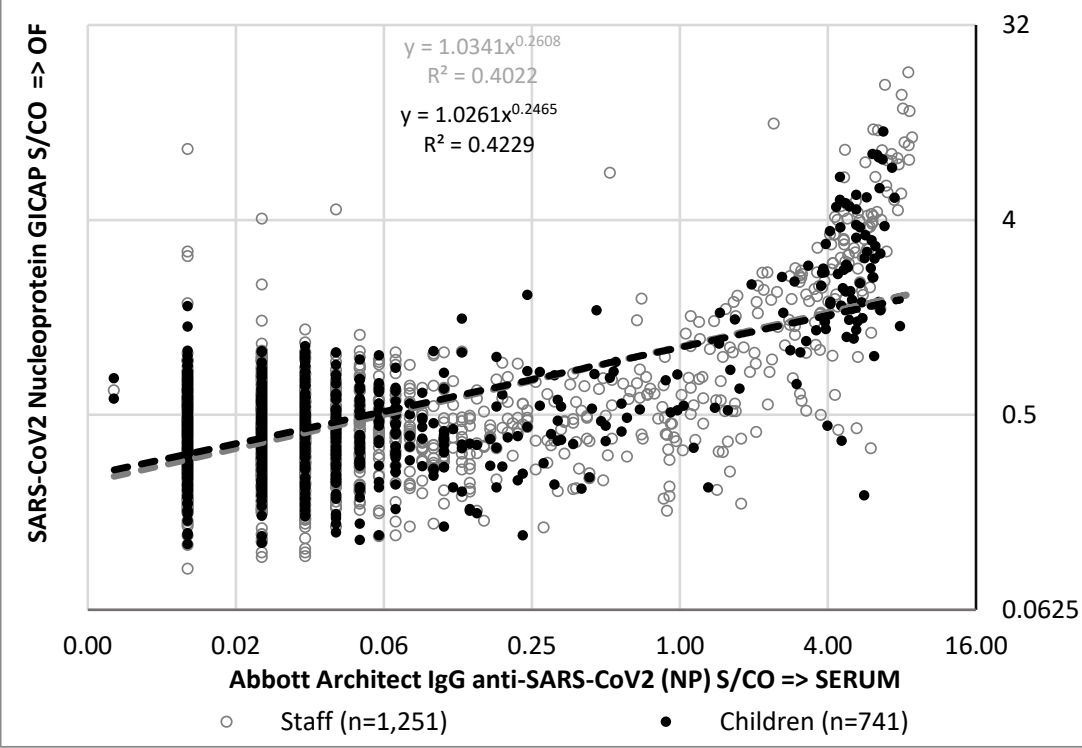


medRxiv preprint doi: https://doi.org/10.1101/2021.07.07.21260121; this version posted July $7,2021$. The copyright holder for this preprint (which was not certified by peer review) is the author/funder, who has granted medRxiv a license to display the preprint in perpetuity.

All rights reserved. No reuse allowed without permission.

Figure 2: Distribution of total IgG in OF by serum result (from Abbot Architect analyser)

439

440

441

442

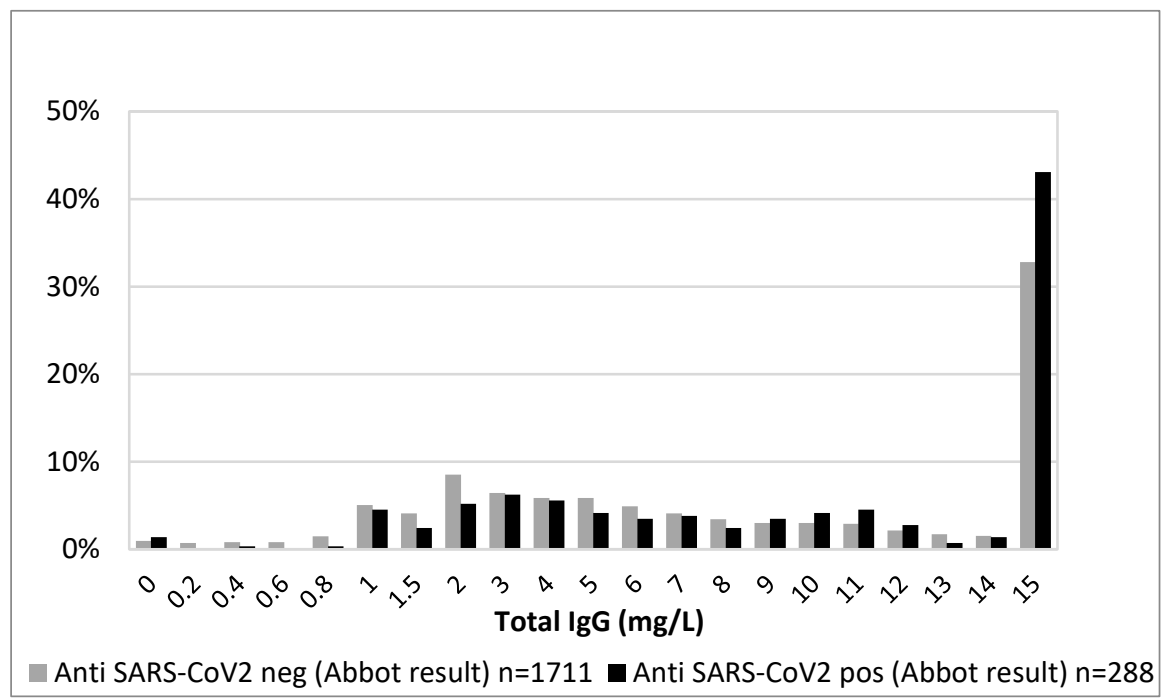

Figure 3: Scattergram of Total IgG measured in Oral Fluid by age of subject (children only; 708 children with known age included. Dotted line indicates trend)

447

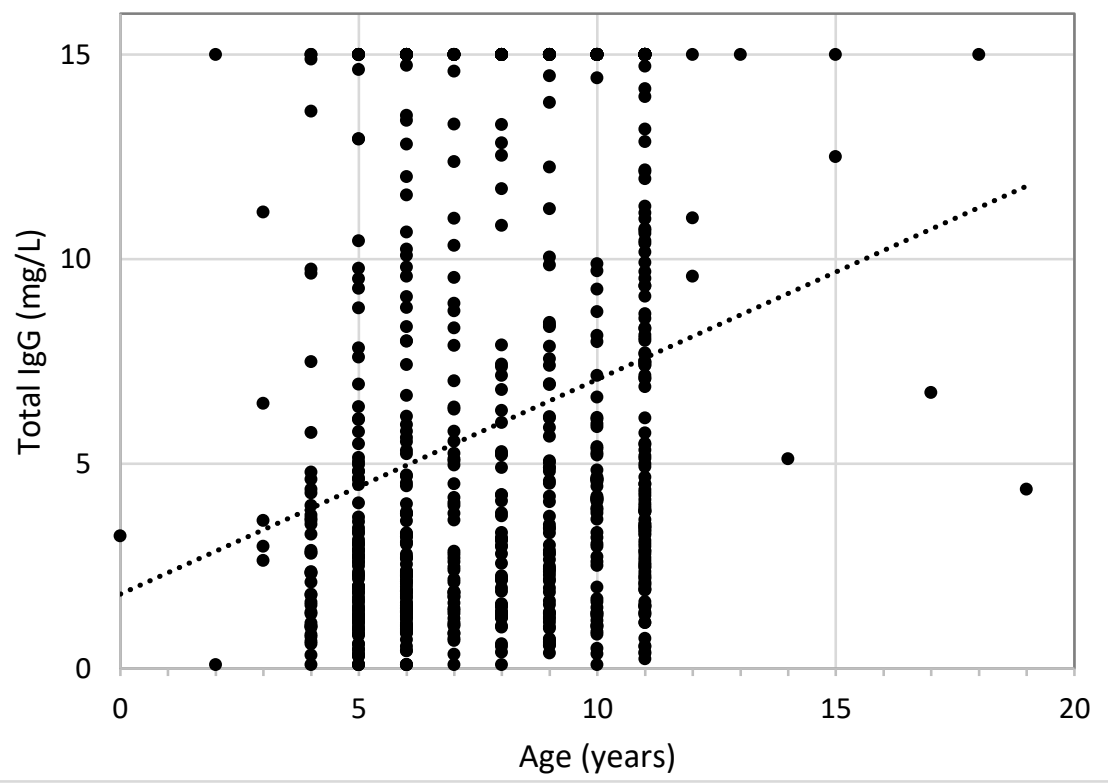


medRxiv preprint doi: https://doi.org/10.1101/2021.07.07.21260121; this version posted July 7, 2021. The copyright holder for this preprint (which was not certified by peer review) is the author/funder, who has granted medRxiv a license to display the preprint in perpetuity.

All rights reserved. No reuse allowed without permission.

Figure 4: Scattergrams of total lgG concentration (in $\mathrm{mg} / \mathrm{L}$ ) determined in oral fluids versus test result
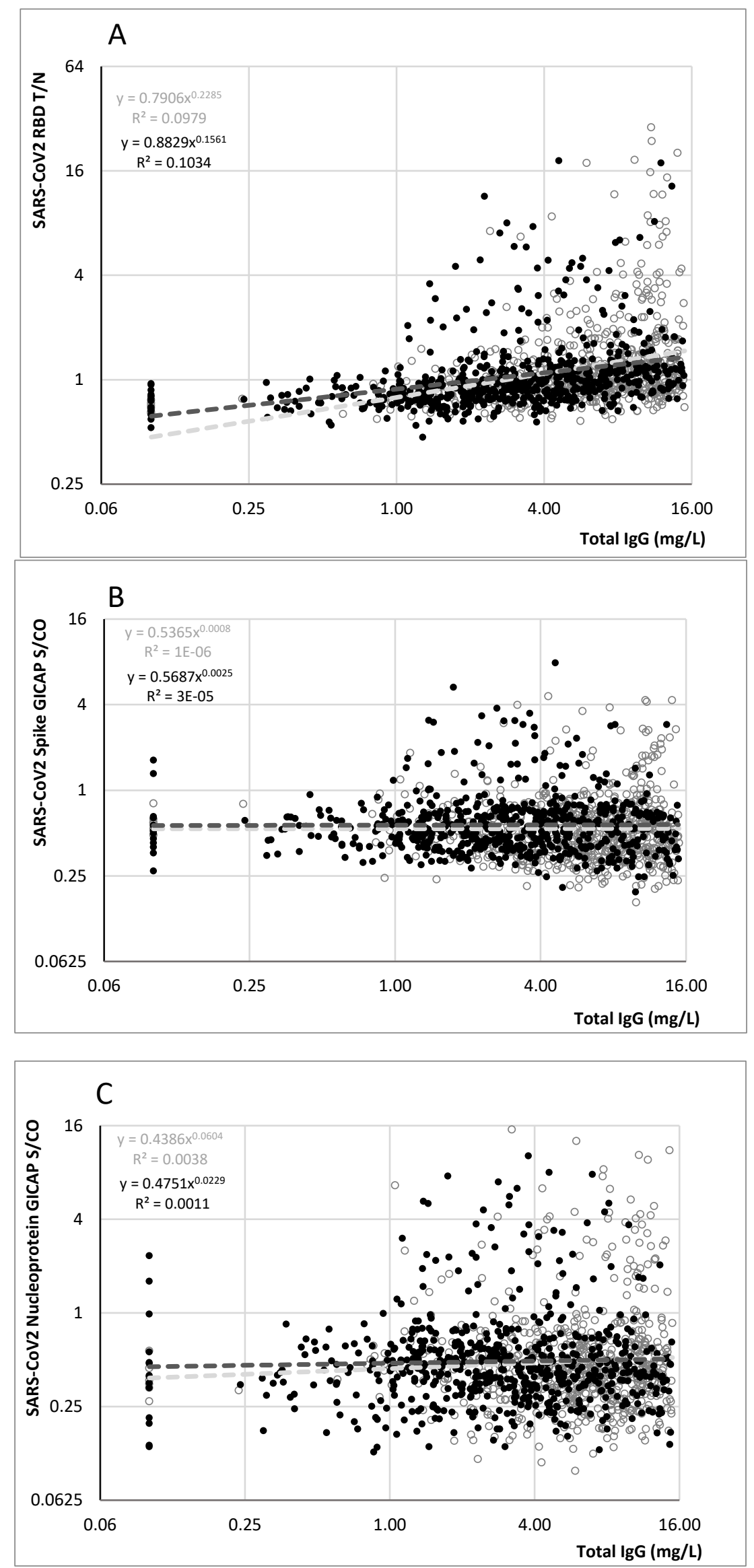
medRxiv preprint doi: https://doi.org/10.1101/2021.07.07.21260121; this version posted July $7,2021$. The copyright holder for this preprint (which was not certified by peer review) is the author/funder, who has granted medRxiv a license to display the preprint in perpetuity.

All rights reserved. No reuse allowed without permission.

\section{Supplement}

Table S1: Summary of participant characteristics

\begin{tabular}{|c|c|c|c|}
\hline & Staff (Adults) & Children & Total \\
\hline Number of participants & 1253 & 746 & 1999 \\
\hline Period of collection & \multicolumn{3}{|c|}{$28^{\text {th }}$ May $-10^{\text {th }}$ July } \\
\hline Male (\%) & $242(19.31 \%)$ & $377(50.54 \%)$ & $619(30.97 \%)$ \\
\hline Sex unknown & $30(2.39 \%)$ & $21(2.82 \%)$ & $51(2.55 \%)$ \\
\hline Age at sampling median (min - max) & 43 (22-71yrs) & 8 (0-19yrs) & 11 (0-71yrs) \\
\hline Age unknown & $750(59.86 \%)$ & $37(4.96 \%)$ & $787(39.37 \%)$ \\
\hline Oral fluids with paired serum analysed in Abbot & $1253(100.00 \%)$ & $746(100.00 \%)$ & $1999(100.00 \%)$ \\
\hline Paired OF with result in $\mathrm{N}$ capture & 1251 (99.84\%) & 741 (99.33\%) & $1992(99.65 \%)$ \\
\hline Paired OF with result in S capture & 1251 (99.84\%) & 741 (99.33\%) & 1992 (99.65\%) \\
\hline Paired OF with result in RBD indirect & $1253(100.00 \%)$ & $746(100.00 \%)$ & $1999(100.00 \%)$ \\
\hline $\begin{array}{l}\text { OF with results for all three OF ELISA's and data } \\
\text { on total IgG }\end{array}$ & 1251 (99.84\%) & $741(99.33 \%)$ & 1992 (99.65\%) \\
\hline
\end{tabular}

Figure S1: ROC Analysis
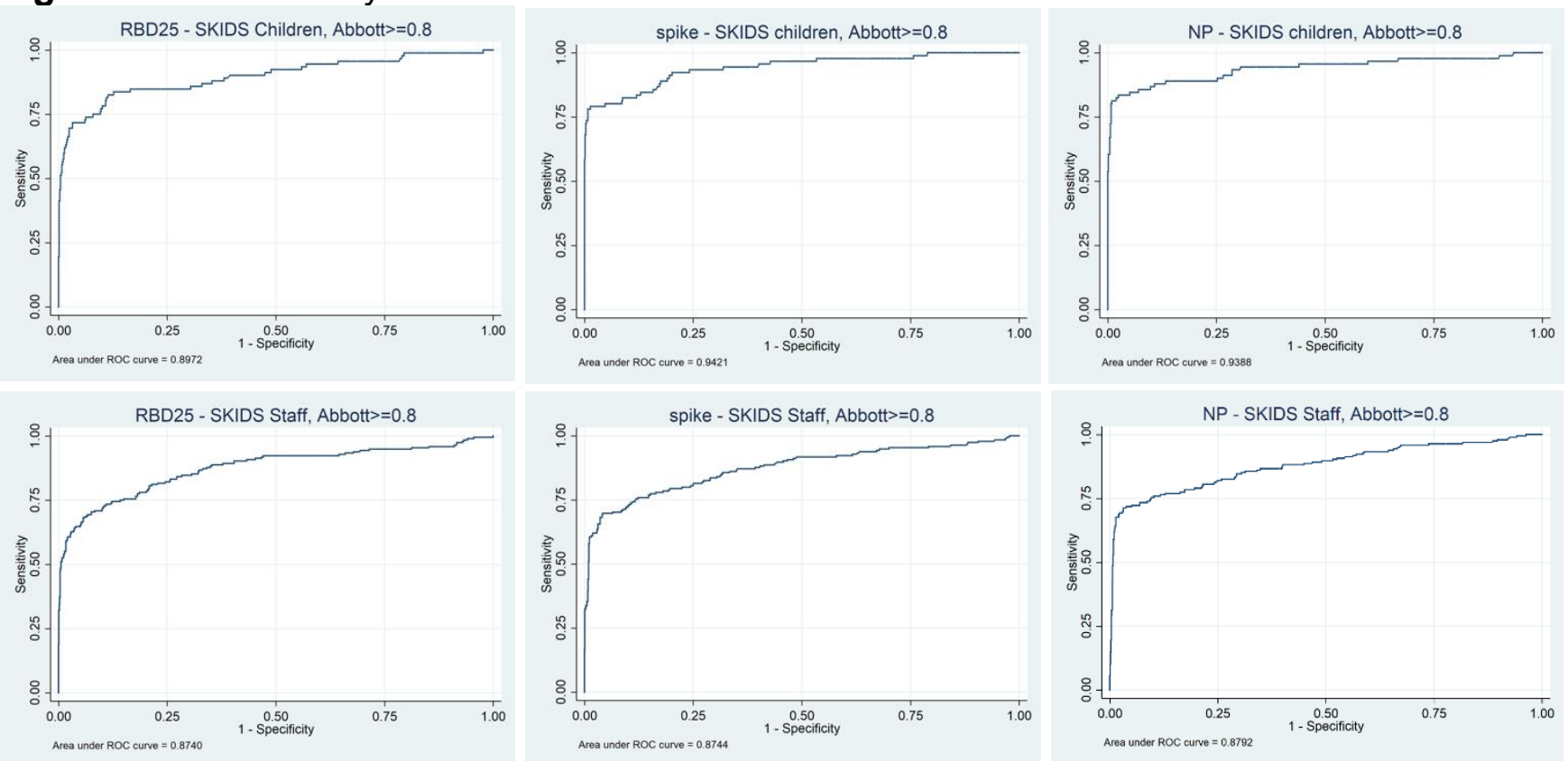

Area Under the Curve results (95\% confidence Intervals)

\begin{tabular}{|l|l|l|l|}
\hline Assay & RBD & Spike & NP \\
\hline sKIDS child & $0.897(0.873-0.918)$ & $0.942(0.923-0.958)$ & $0.939(0.92-0.955)$ \\
\hline sKIDS adult & $0.874(0.854-0.892)$ & $0.874(0.855-0.892)$ & $0.879(0.86-0.897)$ \\
\hline
\end{tabular}

ROC (vs Abbot $>=0.8$ ) 
medRxiv preprint doi: https://doi.org/10.1101/2021.07.07.21260121; this version posted July 7,2021 . The copyright holder for this preprint (which was not certified by peer review) is the author/funder, who has granted medRxiv a license to display the preprint in perpetuity.

All rights reserved. No reuse allowed without permission.

470

471

472

473

474

475

Table S2: Sensitivity and Specificity at a range of cut-offs based on serostatus determined by Abbot Architect (cut-off at 0.8)

\begin{tabular}{|c|c|c|c|c|c|c|c|c|c|c|c|c|c|c|c|}
\hline & $\begin{array}{l}\text { RBD } \\
\text { cut }\end{array}$ & $n / N$ & Sens & $n / N$ & Spec & $\begin{array}{l}\text { NP } \\
\text { cut }\end{array}$ & $n / N$ & Sens & $n / N$ & Spec & $\begin{array}{l}\text { Spi } \\
\text { cut }\end{array}$ & $n / N$ & Sens & $n / N$ & Spec \\
\hline \multirow{7}{*}{ 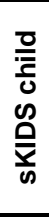 } & 2 & $66 / 92$ & $0.72(0.61-0.81)$ & $633 / 654$ & $0.97(0.95-0.98)$ & 0.7 & 79/91 & $0.87(0.78-0.93)$ & $582 / 650$ & $0.90(0.87-0.92)$ & 0.7 & $79 / 91$ & $0.87(0.78-0.93)$ & $540 / 650$ & $0.83(0.8$ \\
\hline & 2.2 & $62 / 92$ & $7-0.77)$ & $38 / 654$ & & 0.8 & $77 / 91$ & 76-0.91) & $617 / 650$ & .97) & 0.8 & $73 / 91$ & $.71-0.88)$ & 650 & \\
\hline & 2.4 & $58 / 92$ & $0.63(0.52-0.73)$ & $43 / 654$ & $0.98(0.97-0.99)$ & 0.9 & $76 / 91$ & $34(0.74-0.91)$ & $631 / 650$ & $7(0.96-0.98)$ & 0.9 & $72 / 91$ & $79(0.69-0.87)$ & $636 / 650$ & -0.99) \\
\hline & 2.6 & $53 / 92$ & $0.58(0.47-0.68)$ & $647 / 654$ & $0.99(0.98-1)$ & 1 & $73 / 91$ & $0.80(0.71-0.88)$ & $644 / 650$ & $.99(0.98-1)$ & 1 & $71 / 91$ & $0.78(0.68-0.86)$ & $645 / 650$ & $.98-1)$ \\
\hline & 2.8 & $51 / 92$ & $0.55(0.45-0.66)$ & $648 / 654$ & 0.99 & 1.1 & $71 / 91$ & $.78(0.68-0.86)$ & $645 / 650$ & $8-1)$ & 1.1 & $66 / 91$ & $0.73(0.62-0.81)$ & $648 / 650$ & 1) \\
\hline & 3 & $49 / 92$ & $0.53(0.43-0.64)$ & \begin{tabular}{|l|}
$649 / 654$ \\
\end{tabular} & -1) & 1.2 & $69 / 91$ & (6-0.84) & $645 / 650$ & & 1.2 & $59 / 91$ & $0.75)$ & 650 & \\
\hline & 3.2 & $47 / 92$ & $0.51(0.40-0.62)$ & $650 / 654$ & 0.99 (0.98-1) & 1.3 & $65 / 91$ & $0.71(0.61-0.80)$ & $646 / 650$ & $0.99(0.98-1)$ & 1.3 & $52 / 91$ & $0.57(0.46-0.68)$ & $650 / 650$ & 1 (0.99-1) \\
\hline \multirow{7}{*}{ 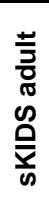 } & 2 & $137 / 196$ & $0.70(0.63-0.76)$ & 977/1057 & $0.92(0.91-0.94)$ & 0.7 & $148 / 195$ & $0.76(0.69-0.82)$ & $941 / 1056$ & $89(0.87-0.91)$ & 0.7 & $151 / 195$ & $0.77(0.71-0.83)$ & $896 / 1056$ & 33-0.87) \\
\hline & 2.2 & $134 / 196$ & .75) & $995 / 1057$ & 0.94 & 0.8 & \begin{tabular}{|l|l|}
$141 / 195$ \\
\end{tabular} & .79) & 986 & 95) & 0.8 & 195 & .77) & 056 & \\
\hline & 2.4 & $127 / 196$ & $0.65(0.58-0.72)$ & $1006 / 1057$ & $0.95(0.94-0.96)$ & 0.9 & $140 / 195$ & $5-0.78)$ & 1016/1056 & 0.96 & 0.9 & \begin{tabular}{|l|}
$128 / 195$ \\
\end{tabular} & .72) & $1022 / 1056$ & 98) \\
\hline & 2.6 & $124 / 196$ & $0.63(0.56-0.70)$ & $1019 / 1057$ & $0.96(0.95-0.97)$ & 1 & $131 / 195$ & $0.67(0.60-0.74)$ & $1041 / 1056$ & $0.99(0.98-0.99)$ & 1 & $113 / 195$ & $0.58(0.51-0.65)$ & $1044 / 1056$ & $0.99(0.98-0.99)$ \\
\hline & 2.8 & \begin{tabular}{|l|}
$122 / 196$ \\
\end{tabular} & $0.62(0.55-0.69)$ & $1026 / 1057$ & $0.97(0.96-0.98)$ & 1.1 & 125/195 & $0.64(0.57-0.71)$ & $1043 / 1056$ & $0.99(0.98-0.99)$ & 1.1 & 99/195 & $0.51(0.44-0.58)$ & $1046 / 1056$ & $0.99(0.98-1)$ \\
\hline & 3 & $117 / 196$ & 0.60 & $1035 / 1057$ & 0.98 & 1.2 & $121 / 195$ & $5-0.69)$ & $1044 / 1056$ & $3-0.99)$ & 1.2 & $86 / 195$ & $7-0.51)$ & $1047 / 1056$ & 0.9 \\
\hline & 3.2 & $109 / 196$ & $0.56(0.49-0.63)$ & $1039 / 1057$ & $0.98(0.97-0.99)$ & 1.3 & $119 / 195$ & $0.61(0.54-0.68)$ & $1045 / 1056$ & $0.99(0.98-1)$ & 1.3 & 78/195 & $0.40(0.33-0.47)$ & $1047 / 1056$ & $0.99(0.98-1)$ \\
\hline
\end{tabular}

476 